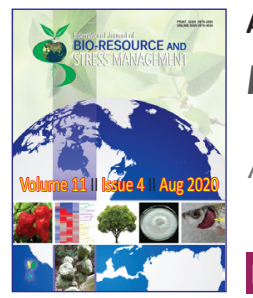

\title{
Ecosystems and History of Evolution and Spread of Sugar Producing Plants in the World-an Overview
}

\author{
Rajendra Prasad and Yashbir Singh Shivay*
}

Division of Agronomy, ICAR-Indian Agricultural Research Institute, New Delhi (110 012), India

Corresponding Author
Yashbir Singh Shivay
e-mail: ysshivay@hotmail.com
Citation: Prasad and Shivay, 2020. Ecosystems and
History of Evolution and Spread of Sugar Producing
Plants in the World-an Overview. International Journal
of Bio-resource and Stress Management 2020, 11(4),
i-iv. HTTPS://DOI.ORG/10.23910/1.2020.2126c

Copyright: (c) 2020 Prasad and Shivay. This is an open access article that permits unrestricted use, distribution and reproduction in any medium after the author(s) and source are credited.

Data Availability Statement: Legal restrictions are imposed on the public sharing of raw data. However, authors have full right to transfer or share the data in raw form upon request subject to either meeting the conditions of the original consents and the original research study. Further, access of data needs to meet whether the user complies with the ethical and legal obligations as data controllers to allow for secondary use of the data outside of the original study.

Conflict of interests: The authors have declared that no conflict of interest exists.

\begin{abstract}
Plants used for making sugar differ from ecosystem to ecosystem of the world and history has played a great role in their spread. People in the tropics and sub-tropics (Papua New Guinea, China, and India) were the first to domesticate sugarcane, numerous sugars producing plant in the World. ICAR-Sugarcane Breeding Institute, Coimbatore in India was the first to do the breeding work in sugarcane and the Coimbatore canes or varieties developed from them dominate the sugarcane producing areas in the world. Indians first made jaggery (Gur) by concentrating the juice by boiling it and cooling it in earthen pots. They were also the first to develop crystal white sugar producing technology in the beginning centuries of CE. Of course, it was later improved by the British, who dominated the European sugar market. Europeans, specially Poles, Germans and French domesticated sugar beet and developed technology for making sugar from it. Aboriginal in North America were the first to develop the technology for making sweet syrup from maple tree and the migrants from Europe then further improved it. Canada is the world's leading country in exporting maple syrup today. People in the southern states of US developed sweet sorghum for making sorghum syrup. Corn producers in USA developed the technology for making corn syrup.
\end{abstract}

Keywords: Corn, maple sorghum syrup, jaggery, sugar, sugar beet, sugarcane

\section{Introduction}

Sugar trade in the world today involves billions of US\$ and for several countries it is their main export product controlling their economy and therefore deserves discussion. A good dinner is incomplete only without a sweet dessert and a candy or chocolate always brings a smile on a child's face. All this is due to sugar, Asia's gift to the entire world. The only sweetener known to Europeans was honey (contains about 30-33\% each of fructose and glucose, $<10 \%$ maltose and some other ingredients). Sugar is chemically sucrose, which is a disaccharide, a molecule of which is made up of one molecule each of glucose and fructose. About $80 \%$ of the world's sugar is made from sugarcane and $20 \%$ from sugar beet.

\section{Tropical Ecosystems}

\subsection{Sugarcane}

People in Papua New Guinea, some 10 thousand years ago successfully domesticated sugarcane species Saccharum officinarum. The second
Article History

RECEIVED in $20^{\text {th }}$ June 2020 RECEIVED in revised form $17^{\text {th }}$ July 2020 ACCEPTED in final form $18^{\text {th }}$ July 2020 
domestication center is mainland southern China and Taiwan where the species was Saccharum sinense. The third place of origin of sugarcane was India for species Saccharum barberi. Being more juicy and sweeter, Saccharum officinarum gradually replaced other Saccharum species throughout South and Southeast Asia (Blust, 1984-1985; Spriggs, 2015). Knowledge of this incredible plant slowly moved across Southeast Asia, southern China, until it reached India. As regards Europeans, sugarcane was first discovered by the Greeks, as the soldiers of Alexander the Great in their raid on India in early $4^{\text {th }}$ century discovered reeds with sweet juice. Later on the other Europeans discovered it during crusades in the $11^{\text {th }}$ century. Extraction of sugarcane juice from the sugarcane plant, and the subsequent domestication of the plant in tropical Southeast Asia were done sometime around 4,000 BC. Sugarcane breeding was started at Indian Council of Agricultural Research, Sugarcane Breeding Research Institute (ICAR-SBI) in Tamil Nadu state of India in 1912 (Dutt and Rao, 1956; Nair, 2011). The institute was involved in early research into hybridization of sugarcane species, and a first attempt to improve the subtropical types of sugarcanes based on wild sugarcane species Saccharum spontanium and Saccharum officinarum resulted in 50 percent improvement in cane yield. The first variety developed was Co 205 (All varieties developed at ICAR-SBI have a prefix Co). The sugarcane varieties were developed by inter-specific hybridization, back crossing of the hybrids to Saccharum officinarum followed by intercrossing of the back crosses derivatives. Apart from ICAR-SBI, 23 state research stations also contribute to the sugarcane varietal development in India. The current breeding strategy is that of a centralized hybridization programme at Coimbatore followed by progeny evaluation and selection at the 23 research stations located across the country to identify improved locationspecific varieties. Consequently the varieties bred by ICAR-SBI and the associate centres occupy over $90 \%$ of the cane area in the country. The sugarcane varieties developed at ICAR-SBI were also exported to Cuba and the United States and today most cane grown in the world is either a Coimbatore cane or a variety developed from a Coimbatore cane. This is a major contribution of India in sugar production.

Sugarcane was introduced to Hawaii by its first inhabitants in 1841 (Deerr, 1949). Sugarcane and pineapple plantations were the largest employers in Hawaii. Portuguese introduced sugar plantations in the 1550's off the coast of their Brazilian settlement colony, located on the island Sao Vincente (Saunders, 2005). As the Portuguese and Spanish maintained a strong colonial presence in the Caribbean.

As regards sugarcane cultivation in mainland US, it was first planted in New Orleans in 1751 by French Jesuit priests, but Caribbean sugarcane had already accounted for a large part of New York City trade by the 1720s. After Étienne de Boré introduced sugar refining to Louisiana in 1795, sugarcane production in Louisiana expanded dramatically; sugar was grown on plantations using slave labour (Gibran, 2019).
Sugarcane is also now grown in other southern US states.

Indians were the first to produce white crystalline sugar sometime after the first century CE. The derivation of the word "sugar" is thought to be from Sanskrit sharkarā meaning crystalline. The invention of manufacture of cane sugar granules from sugarcane juice in India a little over two thousand years ago, followed by improvements in refining the crystal granules in India in the early centuries of CE. Now of course modern sugar mills are completely mechanized, having big steel rollers for crushing cane, and centrifuges for refining the juice, big boilers and crystallization tanks (Honig, 1953). Britishers played a key role in developing sugar industry in India and in early days dominated the European market in sugar. Sugar has been produced in the Indian subcontinent since ancient times and its cultivation spread from there into modern-day Afghanistan through the Khyber Pass, through land way before the opening of sea route. It was neither plentiful nor cheap in early times, and in most western parts of the world and honey was more often used for sweetening.

Today the top five countries sugarcane and sugar are Brazil, India, China, Thailand and Pakistan (Table 1).

\begin{tabular}{llc}
\hline $\begin{array}{l}\text { Table 1: Ten largest sugarcane producing countries of the } \\
\text { World }\end{array}$ & \\
\hline Sl. No. & Country & Million tonnes \\
\hline 1. & Brazil & 739.3 \\
2. & India & 341.2 \\
3. & China & 125.5 \\
4. & Thailand & 100.1 \\
5. & Pakistan & 63.8 \\
6. & Mexico & 56.8 \\
7. & Columbia & 34.9 \\
8. & Indonesia & 33.7 \\
9. & Philippines & 31.9 \\
10. & USA & 27.9 \\
11. & Total & $1,555.1$ \\
\hline
\end{tabular}

Source: UN (from World Atlas)

\subsubsection{Jaggery or gur}

One of the important processes in making white sugar is separation of sugar crystals from liquid impurities in sugarcane juice (known as molasses) by centrifugation. A lot of sugarcane, which is not sold to a sugar factory, is concentrated in open ovens and concentrated juice is condensed in pots of different shapes and sizes. This concentrated product of cane juice without separation of the molasses is known as jaggery or gur. It can vary from golden brown to dark brown in colour. It contains up to $50 \%$ sucrose, up to $20 \%$ invert sugars, and up to $20 \%$ moisture, with the remainder made up of other insoluble matter, such as wood ash, proteins, and bagasse fibres. Gur 
can also be made from palm (taad) sap. A large part of gur is used for making candies by mixing its hot solution with puffed rice (Oryza sativa) or cotyledons of gram or garbanzo (Cicer arietinum) or peanut (Arachis hypogea) or sesame (Sesamum indicum) seeds. This candy is much sought after in fall-winter in India. Gur is used for many sweet preparations and even making cool soft drinks in summer. Muzaffarnar in the state of Uttar Pradesh and Kolhapur in Maharashtra state of India are big market for Gur. Gur is said to have several health benefits. In addition to calories, it supplies several essential minerals, helps in digestion, improves immune system, helps in overcoming cold and to women during menstruation.

\subsection{Palm gur}

Palm sugar or gur is produced from sap (toddy) from the flowers of the trees. The predominant palms sugars are the Palmyra, date, nipa, sugar and coconut palms. There are two major species which Phoenix dactylifera and Phoenix sylvestris. Phoenix dactylifera is common in the Mediterranean and Middle East, while Phoenix sylvestris is native to Asia, mainly Pakistan and India.

\subsection{Sorghum syrup}

Sorghum syrup had been extracted from the stalk of sweet sorghum (Sorghum bicolor) in southern states of USA since the middle of $19^{\text {th }}$ century (Bitzer, 2002). It is also grown in many other countries, such as, Nigeria, India and Mexico. In the past sorghum syrup and hot biscuits were a traditional breakfast in the Southern United States. Sorghum syrup is used for topping on pancakes, cornmeal mush, grits and other hot cereals. It has a molasses flavour. With the declining availability of farm labour, sorghum syrup production has fallen drastically in recent years and currently, less than 1 million US gallons are produced annually in USA. It is facing tough competition with corn syrup.

\section{Temperate Ecosystems}

\subsection{Sugar beet}

Cold European countries could not grow sugarcane, which is a tropical plant and they developed sugar beet (Beta vulgaris) for this purpose. Modern sugar beets date back to mid-18 ${ }^{\text {th }}$ century Silesia (a historical region of central Europe mostly today's Poland, with small parts in the Czech Republic and Germany) where the king of Prussia (a historically prominent German state that originated in 1525) subsidized experiments aimed at processes for sugar extraction (Hill and Langer, 1991; Hanelt et al., 2001). In 1747, Andreas Sigismund Marggraf, a German chemist from Berlin, isolated sugar from beetroots and found them at concentrations of 1.3-1.6\%. $\mathrm{He}$ also demonstrated that the sugar that could be extracted from beets was identical to that produced from sugarcane. His student, Franz Karl Achard, evaluated 23 varieties of mangelwurzel for sugar content and selected a local strain from Halberstadt in modern-day Saxony-Anhalt, Germany. Moritz Baron von Koppy and his son further selected from this strain for white, conical tubers. The selection was named weißeschlesische Zuckerrübe, meaning white Silesian sugar beet, and boasted about 6\% sugar content (Hill and Langer 1991; Hanelt et al., 2001). This selection is the progenitor of all modern sugar beets. A royal decree led to the first factory devoted to sugar extraction from beetroots being opened in Kunern, Silesia (now Konary, Poland) in 1801. The Silesian sugar beet was soon introduced into France, where Napoleon opened schools specifically for studying the plant. He also ordered that 28,000 hectares of land be devoted to growing the new sugar beet (Hill and Langer 1991; Jules, 1912). Now about 250 million tonnes of sugar beet is grown each year (with Russia leading with a production of 39.2 million tonnes (Table 2).

Table 2: The top sugar beet producing countries in 2013

\begin{tabular}{llc}
\hline Rank & Country & $\begin{array}{c}\text { Production (Million } \\
\text { tonnes) }\end{array}$ \\
\hline 1. & Russia & 39.2 \\
2. & France & 33.6 \\
3. & United States & 29.8 \\
4. & Germany & 22.8 \\
5. & Turkey & 16.5 \\
6. & China & 12.1 \\
7. & Ukraine & 10.8 \\
8. & Poland & 10.6 \\
9. & Egypt & 10.0 \\
10. & United Kingdom & 8.0 \\
11. & Total & 250.2 \\
\hline
\end{tabular}

Source: World Atlas (from internet)

\subsection{Maple syrup}

Sap of maple (Acersp.) tree is used for making maple syrup and maple sugar. This is a major contribution of Canada to world sugar sugary products. The Canadian province of Quebec is by far the largest producer, responsible for $>80$ percent of the world's output; Canadian exports of maple syrup in 2019 were about US\$ 324 million, with Quebec accounting for some 90 percent of this total. The syrup is extracted from the xylem sap of sugar maple, red maple and black maple trees and other maple tree species. According to aboriginal oral traditions, as well as archaeological evidence, maple tree sap was being processed into syrup long before Europeans arrived in the region (Koelling et al., 1966). In the 1970 s several technological improvements were made in syrup processing.

Maple syrup contains $32 \%$ water, $67 \%$ carbohydrates $(90 \%$ of which are sugars), and no appreciable protein or fat. It also contains small amounts of vitamins and minerals. Maple syrup contains a wide variety of polyphenols and volatile organic compounds, including vanillin, hydroxybutanone, lignans, propionaldehyde, and numerous organic acids. It is not yet 
known exactly all compounds responsible for the distinctive flavour of maple syrup, although primary flavour-contributing compounds are maple furanone (5-ethyl-3-hydroxy-4-methyl$2(5 \mathrm{H})$-furanone), strawberry furanone, and maltol (Chartier, 2012). In addition to topping the pancakes and popcorn, maple syrup is used for flavoring several items in bakery ad cookery, such as donuts, pies, scones, fajitas, soups, vegetable salads and even in cocktails.

\subsection{Corn syrup}

Corn syrup is an American contribution. Corn syrup is made by inverting the starch in corn to glucose and fructose. Historically, corn syrup was produced by combining corn starch with dilute hydrochloric acid, and then heating the mixture under pressure. The process was invented by the German chemist Gottlieb Kirchhoff in 1812. Currently, corn syrup is obtained through a multi-step bioprocess. First, the enzyme $\alpha$-amylase is added to a mixture of corn starch and water. The $\alpha$-amylase breaks down the starch into oligosaccharides, which are then broken into glucose by adding the enzyme gluco-amylase, known also as " $\gamma$-amylase". The glucose can then be transformed into fructose by passing the glucose through a column that is loaded with the enzyme D-xylose isomerase (Chaplin and Christopher, 1990).

\subsection{Sugarcane juice syrup or raab}

Juice from sugarcane grown on calcareous alkaline soils contains too many salt impurities and it cannot be crystalized into gur. Therefore, it is stored as liquid known as raab. Mixed with water $r a b b$ is consumed as a summer drink or used for sweetening sattu (a mixed flour of parched barley and gram) in several parts of India. Also, it can be used in making many sweet dishes. It has a distinctive molassy-flavour as in sorghum syrup and is liked by many.

\section{Conclusion}

Sugar has always been in demand by man and he has searched for it from many plants in different times of history and in different ecosystems. Sugar and sugary products are derived from a number of plants, such as sugarcane and sorghum in tropical ecosystems and sugar beet, maple and corn in temperate ecosystems. This paper tends to present a summary of the development of sugar and sweet yielding plants in the world.

\section{References}

Blust, R., 1984-1985. The Austronesian Homeland: A Linguistic Perspective. Asian Perspectives 26 (1), 44-67.

Bitzer, M., 2002. Sweet Sorghum for Syrup. University of Kentucky, Lexington, KY, USA.

Chartier, F., 2012. Taste Buds and Molecules: The Art and Science of Food, Wine, and Flavor. John Wiley \& Sons, USA.

Chaplin, M., Christopher, B., 1990. Enzyme Technology: Cambridge University Press, Cambridge, England. pp: 146-154.

Dutt, N.L., Rao J.T., 1956. Coimbatore canes in cultivation: Indian Central Sugarcane Committee, New Delhi, India

Deerr, N., 1949. The History of Sugar, Volume 1, Chapman and Hall Ltd, London.

Gibran, M.K., 2019. The sugar that saturates the American diet has a barbaric history as the 'white gold' that fueled slavery. The Times Magazine, August 18, 2019, New York.

Honig, P. (Ed.), 1953. Principles of Sugar Technology 1st Edition, Elsevier, USA.

Hill, G., Langer, R.H.M., 1991. Agricultural plants. Cambridge, UK: Cambridge University Press, 197-199.

Hanelt, P., Büttner, R., Mansfeld, R., Kilian, R., 2001. Mansfeld's Encyclopedia of Agricultural and Horticultural Crops. Springer, 235-241.

Jules, H., 1912 Histoire centennale du sucre de betterave; album illustré des reproductions de documents extracts de la collection de M. Jules Hélot; Fortier et Marotte, Paris.

Koelling, M.R., Laing, F., Taylor, F., 1996. History of maple syrup and sugar production. (In) Koelling MR, d Heiligmann RB (Eds.). North American Maple Syrup Producers Manual. Ohio State University (OSU), USA.

Nair, N.V., 2011. Sugarcane varietal development programmes in India: An overview. Sugar Technology 13, 275-280.

Spriggs, M., 2015 Archaeology and the Austronesian expansion: where are we now? Antiquity 85(328), 510-528.

Saunders, N., 2005. The Peoples of the Caribbean: an Encyclopedia of Archeology and Traditional Culture, pp 13. ABC-CLIO Publishers, Santa Barbara, CA, USA. 